\title{
Review of Long-Term Consequences of Maternal Methamphetamine Exposure
}

\author{
R. ŠLAMBEROVÁ ${ }^{1}$ \\ ${ }^{1}$ Department of Physiology, Third Faculty of Medicine, Charles University, Prague, Czech Republic
}

Received March 21, 2019

Accepted October 23, 2019

\begin{abstract}
Summary
Methamphetamine is one of the most abused hard drugs in the Czech Republic. Its popularity is high not only in Eastern Bloc of Europe but is growing in other countries around the world, including the United States. In addition, methamphetamine abuse increases in drug addicts during pregnancy. Although research into the long-term effects of prenatal methamphetamine exposure has been ongoing for many years, the exact mechanism of action and factors that may influence the effect of this drug are still not fully understood. There have been many studies that investigated the effects of addictive substances on the behavior and cognitive function of individuals during adolescence. Some studies have shown prenatal or perinatal influences, e.g. drugs, stress, hypoxia, and malnutrition, can affect drug sensitivity or drug-seeking behavior in adulthood. However, when these factors are most impactful, i.e. prenatal vs. perinatal, and which stages of the prenatal and perinatal periods are the most sensitive to these factors is not yet clear. Our laboratory specializes in research on the effects of drugs (especially methamphetamine) on rat mothers and their offspring during postnatal development, adolescence, and adulthood. This review summarizes our past results on the long-term effects of methamphetamine on the mother and her offspring, its mechanism of action, the role of maternal care, the possible emergence of long-term sensitization, and the critical neurodevelopmental periods for methamphetamine exposure.
\end{abstract}

\section{Key words}

Drug addiction • Methamphetamine • Development • Maternal care $\bullet$ Sensitization $\bullet$ Critical period

\section{Corresponding author}

R. Šlamberová, Department of Physiology, Third Faculty of
Medicine, Ke Karlovu 4, 12000 Praha 2, Czech Republic. Fax: +420 224902 750. E-mail: romana.slamberova@lf3.cuni.cz

\section{Introduction}

We live in hectic times, and maximum performance as well as nearly perfect work is expected without hesitation and regardless of our current physical and mental status. Each of us acts according to a learned pattern of behavior, and each of us has inherent dispositions. However, our social environment (i.e. parents, school and people around us) also strongly impact our actions. Each person is unique in terms of the demands placed on them as well as their ability to respond to these demands. For some, the response to increased stress is depression, anxiety, and illness, while others turn to alcohol, drugs, or other addictive substances as coping mechanisms. In today's modern, stressful environment, addiction is likely to be a problem that will increase and expand.

\section{A short history of drug use}

Drug use has a long history, which no doubt started with natural substances derived from plants. Indian hemp (Cannabis sativa), today used as marijuana and hashish, has been known for more than five millennia. Another plant, the poppy (Papaver somniferum), contains opium, which is found in the dried juice of the unripe poppy. The 25 alkaloids found in opium were isolated during the $19^{\text {th }}$ century. Some of them are well known such as morphine, narcotine, papaverine, and methylmorphine (codeine) (Reynolds 
and Randall 1957). Their discovery was an important advance in the medicine of pain relief. However, their added potency also increased the risk of addiction. In 1875 Alder Wright created diacetylmorphine, which was later name and marketed as heroin by the Bayer company (according to stories, one the German scientists, who tasted it, said it made him feel "heroisch", which in English means heroic). In 1898 it came into use as a substitute for morphine and codeine. Misuse of heroin began mainly after World War II and affected mainly drug users in the U.S., where its "popularity" grew to the point that by $196590 \%$ of all addicts were dependent on heroin.

Another important group of abused substances come from the coca plant (Erythroxylon coca). The bestknown drug in this group is cocaine, an alkaloid first extracted from the leaves of this plant in the second half of the $19^{\text {th }}$ century. This substance, in addition to its analgesic effects, also has hallucinogenic effects, and can cause addiction.

Due to the rapid and powerful physical and psychological dependence caused by these natural substances and their derivatives, it was necessary to look for other substances with the same potent analgesic effect but with less potential to cause addiction. In the late $19^{\text {th }}$ century amphetamine was synthesized for use in medicine; amphetamine continues to have a role in medicine even today. Although amphetamine is an addictive drug with euphoric effects, a more commonly abused drug is its derivate, methamphetamine (MA), which has been used as an anorectic drug. This synthetic psychostimulant drug also has great potential to induce drug addiction.

\section{What is addiction?}

Addiction of all types remains a serious problem. It does not always have to be drug addiction; it can take the form of addiction to alcohol, nicotine, and other chemicals. Additionally, there is gambling addiction and addictions to things like food, cell phones, and computer games. However, the mechanism behind these different addictions seems to have a number of similar features, such as the desire for the unknown, escape from worries, and an inability to break free from the "drug".

Addiction is not synonymous with drug use, instead is a compulsive, chronic use of a drug that continues despite the negative consequences resulting from its use (see DSM-5 2013). This pathological behavior does not occur in all individuals who use drugs. However, it does occur in about $20 \%$ of them. It is considered a disease that requires treatment. During drug abstinence, about $90 \%$ of addicts start taking drugs again, which is typically called a relapse (DeJong 1994). It has long been discussed whether other animals besides humans can develop addictions. Experimental studies have confirmed that the answer to this question is, yes! And just like humans, the occurrence of pathological drug use in animals is also about $20 \%$ (Belin et al. 2008).

Drug addiction does not arise on first use and does not develop for every drug user. A number of factors play a role in addiction, e.g. environmental influences, stress and, genetic disposition. So how does drug addiction arise? A number of studies have shown that drug addiction occurs gradually, starting with the first drug contact and continues with repeated drug use. On first use, the individual gets a sense of satisfaction and is able to forget the worries of everyday life. Later there is a loss of control when the urge to take the drug becomes irresistible; at this point, we can talk about addiction.

The characteristics of drug-dependent individuals include but are not limited to: (1) impulsivity, (2) compulsiveness, (3) novelty-seeking, (4) sensationseeking, and (5) poor decision making. Professor Everitt's group from Cambridge deals with experimental modeling of impulsivity and "new search" behavior in rats and drug addiction (Everitt et al. 2008). Their results suggest that those with higher new search tendencies have an increased desire to try drugs, but this does not necessarily result in drug addiction; high impulsivity was not directly dependent on previous drug exposure (Belin et al. 2008). However, high impulsiveness increases compulsive behavior, despite the negative consequences and consequently can result in drug addiction. Possible mechanisms are changes in dopamine transmission that occur in impulsive individuals.

\section{The importance of the striatum}

Everitt (2005) believes that during the time between the first drug abuse and the appearance of addictive, compulsive behavior, the activation of brain structures is shifted from the prefrontal cortex to the striatum and in the striatum from its ventral portion - the nucleus accumbens (NAc) to the dorsal - caudate/putamen (CP). Chronic drug abuse affects behavior and brain processes that result in excessive and uncontrollable drug 
use. Recurring habits and repeated stimulation of the same brain structures and pathways lead to the development of automatisms and activation of synaptic plasticity, similar to the process of learning (Gerdeman et al. 2003). The central structure in this dependency process is the striatum. The ventral striatum (NAc) and its association with the ventral tegmental area (VTA) form the mesolimbic reward pathway that is activated in the early stages of drug use. Until recently, these structures were considered to be the center of drug addiction. However, more recently, it has been shown that the dorsal striatum (CP) also plays an important role in the development of dependence. The dorsal striatum and its activation seem to result in the transition from trying a new drug to drug dependence, resulting in pathological habits, uncontrollable behavior, and compulsive drug seeking. Changes in the dorsal striatum appear to be due to processes occurring in NAc, which result in the initiation of synaptic plasticity in the dorsal striatum (Gerdeman et al. 2003).

The striatum receives stimuli from the cortex, the thalamus, and the amygdala and passes it to the basal ganglia (Parent 1990). The main mediator of these pathways is glutamate. While the structure and neurotransmitters of the ventral and dorsal striatum are very similar, these structures differ in their afferent and efferent connections. The afferent pathways from the limbic system and the prefrontal cortex lead mainly to the NAc, while efferent pathways lead mainly to the sensorimotor cortex. Another striatum afferent is a dopaminergic pathway from the midbrain. While pathways from VTA go to the NAc, the dorsal striatum (GP) dopaminergic connections come from the substantia nigra (Parent 1990).

Glutamatergic pathways of the striatum can be affected by a variety of neurotransmitters and neuromodulators. Perhaps the most important of these is the dopaminergic system. The dopaminergic system is also influenced, whether directly or indirectly, by the vast majority of abused drugs. Acute administration of most abused drugs induces an increase in extracellular dopamine levels in the striatum either by direct action on the dopaminergic neuron endpoint or by an increase in neuronal activity in the VTA (Berke and Hyman 2000). The mechanism by which drug-activated dopamine acts on the striatum has not yet been fully elucidated, however, the reduction of $\mathrm{D} 2$ dopaminergic receptors observed in both abstaining alcohol and drug users (cocaine, heroin, MA) (Volkow and Wise 2005) suggests an important role for D2 receptors in the formation of dependence.

\section{MA in Europe and the Czech Republic}

MA is a very popular hard drug, which is abused worldwide. Its history in Europe is long. Amphetamine, which was discovered before MA, which was first synthesized in Germany, in 1887 , by a Romanian chemist (Grobler et al. 2011). Shortly afterward in 1893 MA was synthesized from ephedrine by a Japanese chemist (Grobler et al. 2011). During World War II, MA was sold in tablet form under the brand name Pervitin, produced by the Berlin-based Temmler pharmaceutical company. It was used extensively by all branches of the combined Wehrmacht armed forces of the Third Reich, and was particularly popular with Luftwaffe pilots for its performance-enhancing stimulant effects and the extended wakefulness it induced (Defalque and Wright 2011). However, the side effects were so serious that the army sharply reduced its usage in 1940 (Defalque and Wright 2011).

Recent European surveys (2014) conducted by the European Monitoring Center for Drugs and Drug Addiction (EMCDDA) found an increasing number of stimulant users, as well as increasing use of the injectable forms of these drugs compared to previous years. Psychostimulants in general, and in particular MA, were the most commonly used primary drugs. MA is the most commonly confiscated psychostimulant in the Czech Republic, Slovakia, Latvia, and Lithuania. The EMCDDA survey also emphasized that MA production in the Czech Republic is growing, as evidenced by the increase in drug seizures and discoveries of drug homelaboratories. Another problem is that the precursors used for the production of this drug are readily available. In the Czech Republic, a noticeable increase in the high-risk use of MA (especially injections) was observed between 2007 and 2014, an increase from approximately 20,000 users to more than 36,000 (EMCDDA 2016).

Statistics from 2012 showed that there were over 12 million people in the USA who had abused MA during their lifetime. The survey showed that the youngest MA user was only 12 years old (Courtney and Ray 2014). Moreover, MA is a favorite drug among pregnant drugabusing women. Women, especially during pregnancy, take MA because it decreases their appetite and thus helps them control their weight, while also increasing energy levels. Statistics show that only $17 \%$ of female drug abusers in the USA were primary MA users, but $38 \%$ had used MA during pregnancy (Marwick 2000). 


\section{Methamphetamine use during pregnancy}

Drug use during pregnancy is a major problem affecting the health and social life of many individuals. Psychoactive drugs can easily cross the blood-brain barrier (one of the most impervious barriers of the body) and the placental barrier, which is much easier to pass through. As a result, the concentration of the drug in a fetus is usually $50 \%$ of the drug concentration circulating in the mother's body. However, due to slower drug degradation in the fetal liver compared to the mother, the concentration of the drug in the fetus can sometimes exceed the concentration in the mother's body (Dattel 1990). In addition, many drugs can pass into a nursing mother's breast milk and postnatally expose a developing infant to drugs the mother uses (Šlamberová 2012). Therefore, during pregnancy and/or lactation, drugs can affect both the mother's health as well as the development of her baby, either directly (drug effect) or indirectly (malnutrition, hypoxia, maternal care, etc.).

Clinical studies have demonstrated that prenatal MA exposure affects prenatal as well as postnatal development of newborns (for review see (Šlamberová 2012, Viteri et al. 2015)). Exposed children are born smaller, have a smaller head circumference, and can be premature. They may experience increased irritability and tearfulness, decreased reflexes (suction reflex), and have an increased incidence of musculoskeletal disorders (muscle tone disorders). Also, their postnatal development can be slower (both sensorimotor and mental development). Changes in the EEG and a higher incidence of sensory disturbances can also occur. Delayed development can still be evident at pre-school and early school ages. Children can have reduced attention spans and learning difficulties; they may show signs of personality disorders (fury attacks, apathy, and stunted emotions). They often adapt poorly to their environment (social inadaptability). Additionally, they may be more prone to seizures disorders. Follow-up with drug addicts and affected children is incredibly difficult, as such there are currently no clinical trials to monitor the long-term (i.e. into adulthood) effects of prenatal drug exposure.

\section{Limitation of clinical studies - the need for animal models}

No clear conclusion can be drawn since pregnant mothers often use or abuse other substances such as alcohol and nicotine as well as MA. The abuse of multiple dependence-inducing substances is a common problem in monitoring drug effects in humans since it is virtually impossible to distinguish the effects of individual addictive substances. Changes in the placenta that lead to decreased placental perfusion due to vasoconstriction, and poor nutrition (Vavř́nková et al. 2001) can also negatively affect newborns. Regardless of other factors, MA abused during pregnancy is a risk to the fetus, although no specific syndrome associated with MA abuse in the prenatal period has been described and the mechanism of drug action on the fetus is not yet fully understood. Clinical studies are largely limited to statistical comparisons and scientific research in humans is very limited. It is not practical to maintain a sufficiently large group of children from drugdependent mothers for observation until adulthood. Therefore, most of the work examining the effects of prenatal drug use has to be done on laboratory animals.

Our laboratory has been researching the effects of maternal MA administration on mother and progeny since 2002 (illustrating picture of our model Fig. 1). We demonstrated that MA administration during prenatal and early postnatal periods impairs maternal behavior (Šlamberová et al. 2005), delays postnatal sensorimotor development of MA-exposed pups (Hrubá et al. 2009, Šlamberová et al. 2006), and that the impairing effect of prenatal MA exposure persists until adulthood (Šlamberová 2012). Prenatally MA-exposed adult rats have impaired learning and memory (Šlamberová et al. 2005), altered pain sensitivity (Yamamotová and Šlamberová 2012) and seizure response (Bernášková et al. 2011), and decreased levels of social interaction (Šlamberová et al. 2015). All these results are consistent with the clinical studies described above. Our latest studies seek to test three hypotheses.

\section{Hypothesis I - Maternal care can fundamen- tally affect functional changes in prenatally MA-exposed progeny, both in the near and long-term}

Experimental administration of MA to pregnant laboratory mice or rats $(5,10,15$, or $20 \mathrm{mg} / \mathrm{kg})$ leads to drug concentrations in the brain that correspond to the values observed in the fetuses of drug-dependent mothers (Acuff-Smith et al. 1996). These doses, therefore, serve as an experimental model to determine the potential risk from in utero exposure of drugs in humans. There are studies, including our own, demonstrating that amphetamines also impairs maternal behavior (Fraňková 1977, Piccirillo et al. 1980, Šlamberová et al. 2005, Šlamberová et al. 2005) (Fig. 1). 


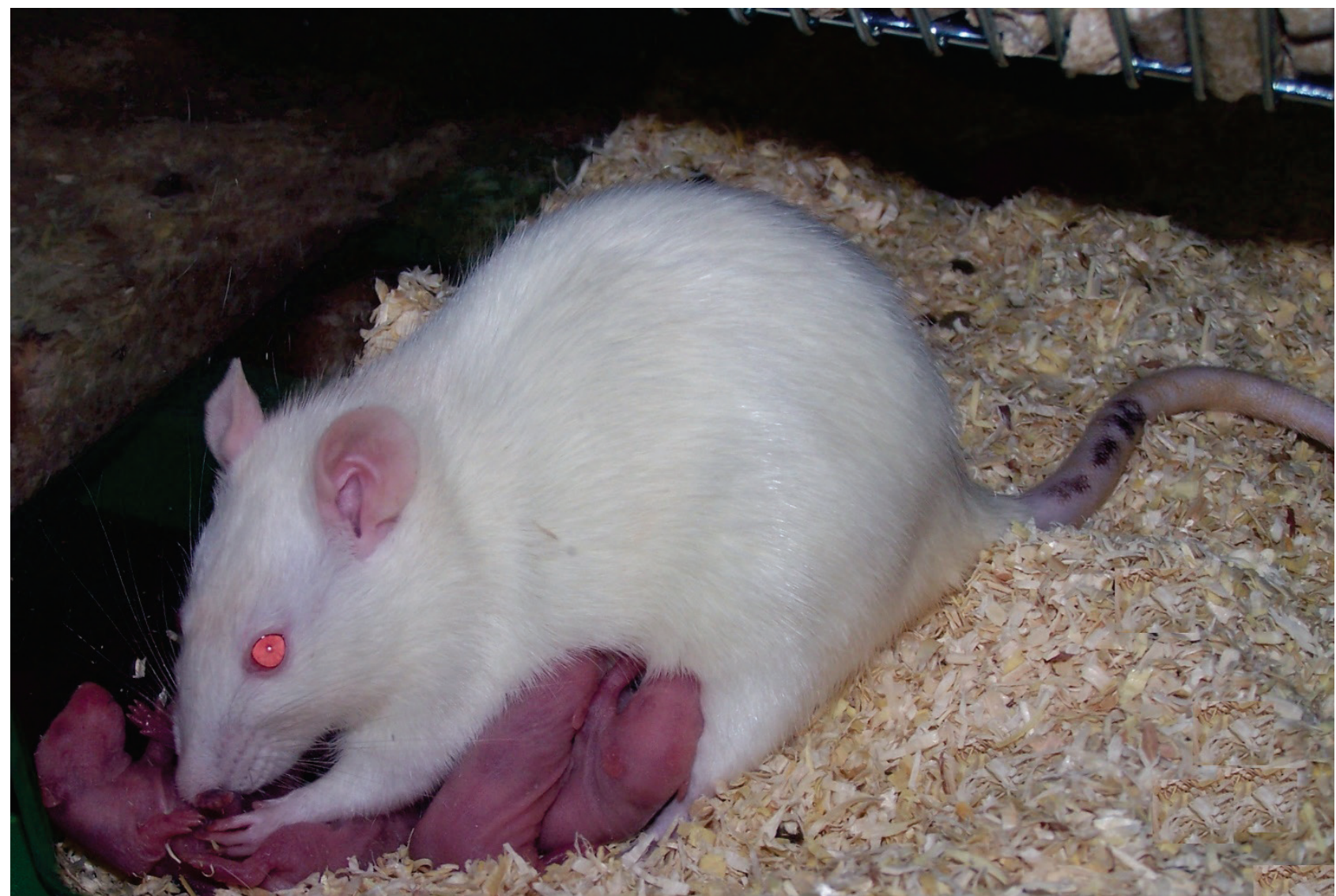

Fig. 1. Picture of nursing rat mother.

Acuff-Smith et al. (1996) further studied the effect of MA on the weight of mothers and pups and found lower weights for both, compared to controls fed ad libitum as well as a group with the same food intake as the drug-exposed animals. Thus, the lower body weight was not caused only by lower nutritional intake and decreased appetite. One of these mechanisms may be a vasoconstrictor effect on the utero-placental blood supply, which further reduces the supply of nutrients to the fetus. The critical phase for the uptake of nutrients appears to be the later stage of embryonic development. To differentiate the effect of vasoconstriction, anorexia, and maternal hypoxia on the developing fetus, Yamamoto et al. (1992) isolated 10.5-day old rat embryos and cultivated them in the presence of different concentrations of MA. They found that the drug had a dose-related effect on yolk sac diameter, the incidence of malformations, and growth disorders. High doses $(50 \mathrm{mg} / \mathrm{kg})$ of prenatal MA lead to eye disorders such as anophthalmia, microphthalmia, and retinal detachment (Acuff-Smith et al. 1992, Acuff-Smith et al. 1996, Vorhees and Acuff-Smith 1990). These findings suggest that repeated administration of MA during pregnancy could have serious long-term effects on offspring. MA administered prenatally has also been shown to increase pup mortality, reduce weight gain, cause developmental delays, and slow reflexes (Acuff-Smith et al. 1996, Cho et al. 1991, Martin et al. 1976).

In agreement with the above-mentioned studies, our results also showed that prenatal exposure negatively affects postnatal development of pups, especially sensorimotor functions and that the impairing effect of MA can also influence the development of future generations (Šlamberová et al. 2006, Šlamberová et al. 2007). However, this impairing effect can be off-set my good postnatal care (Hrubá et al. 2009). Specifically, animals that were raised by MA-exposed mothers during lactation, i.e. had postnatal exposure to MA via breast milk, also displayed delayed development. On the other hand, animals that were exposed to MA prenatally, but were raised by control mothers scored better on tests than their maternal siblings with postnatal MA exposure. This "better care" was independent of the fact that some of the pups were their own and some were adopted, i.e. they were cross-fostered. Studies by (Levine 1994) also support the idea that better maternal care can improve 
pup development. Maternal licking and grooming is a major source of tactile stimulation for developing pups and affects somatic growth and neural development (Levine 1994). Our results, therefore, support the hypothesis that maternal care can fundamentally affect functional changes in prenatally MA-exposed animals, both in the near and long-term, and could serve as a mechanism for a non-genomic, behavioral, mode of transmission of traits.

\section{Hypothesis II - Prenatal MA exposure chan- ges drug susceptibility and drug-seeking behavior in adulthood}

Sensitization or increased sensitivity is defined as the progressive response of an organism to repeated drug administration at the same or even lower doses, manifested by an increased expression of a certain type or pattern of behavior (Suzuki et al. 2004). Various forms of behavior have been described in animals as manifestations of increased sensitization after repeated intermittent drug administration. In the case of rats, it is mainly an increase in locomotion and exploratory activity, or the development of stereotyped forms of behavior (Malanga and Kosofsky 2003). Once animals are sensitized, the increased susceptibility to increased psychomotor activity lasts for months to years (Robinson and Becker 1986, Suzuki et al. 2004).

The neuronal background of increased susceptibility to drugs seems to have phases of development: the first phase is associated with short-term changes at the molecular and cellular level in the ventral tegmental area (VTA), while the sensitization represents permanent adaptations at the level of motivational pathways. From a neurochemical and neuroanatomical point of view, the aforementioned mesolimbic, mesocortical, and nigrostriatal dopamine system play key roles (Robinson and Becker 1986).

Research on increased drug sensitivity has revealed that the use of one drug can lead to an increased sensitivity to another drug. In this case, we are talking about cross-sensitivity to a drug or cross-sensitization (Shuster et al. 1977). So far, cross-sensitivity has been found not only for related drugs, such as amphetamine and cocaine (Horger et al. 1992), and amphetamines and methylphenidate (Valvassori et al. 2007), but also for unrelated drugs such as opioids and cocaine (Leri et al. 2003), and endocannabinoids and opioids (Vela et al. 1998).
Our studies demonstrated that increased susceptibility to MA and amphetamine (Macúchová et al. 2016, Šlamberová et al. 2011) after prenatal administration of MA using the Laboras test and the open arena test, both of which showed increased locomotor and exploratory activity after exposure. In females, crosssensitization was also found after acute administration of MDMA and cocaine (Šlamberová et al. 2013), suggesting sex differences relative to acute drug administration. The sensitizing effect of prenatal MA exposure was also confirmed by Bubeníková-Valešová et al. (2009), in which increased locomotion, seen after acute MA exposure of prenatally MA-expose animals, correlated with an increase in dopamine levels in the NAc. Similarly, dopamine levels in the hippocampus also corresponded with cognitive function in prenatally MA-exposed animals (Fujáková-Lipski et al. 2017). It is interesting to note that even though prenatal exposure to MA triggered altered sensitivity to psychostimulants, it did not lead to active searching in the conditional drug search (CPP) test (Šlamberová et al. 2011). Even animals exposed to MA in utero preferred in the CPP to an environment that was not associated with cocaine application, suggesting tolerance to cocaine more than sensitization (Šlamberová et al. 2013, Šlamberová et al. 2012). When testing acute drug applications using drugs that have different mechanisms of action than MA (e.g. morphine and THC), we did not find increased sensitivity to these drugs in animals with prenatal MA exposure (Šlamberová et al. 2013, Šlamberová et al. 2012). Thus, a drug's mechanism of action in adults, i.e. on neurotransmitter systems, seems to play a key role in sensitization. Our results suggest that sensitization after prenatal MA is mainly associated with the same drug in adulthood or to drugs with a similar mechanism of action. Compared to studies testing the effect of prenatal cocaine exposure (Estelles et al. 2006, Rocha et al. 2002), prenatal MA exposure appears to induce weaker sensitization to drugs in adulthood.

Based on studies showing that prenatal exposure to cocaine causes increased sensitivity and increased active drug-seeking behavior in adulthood, regardless of the mechanism of action, we expected similar results after prenatal exposure to MA. However, our results have shown that prenatal exposure to MA, although it can cause, in some cases, altered sensitivity to the drug, does not induce active drug-seeking. Therefore, it seems that the long-term effects of MA are weaker than the longterm effects of cocaine. Because MA is the world's most 
widely used drug among drug-addicted pregnant women, our results qualify as a slightly positive finding. It is therefore likely that the offspring of women addicted to MA during pregnancy will not manifest increased desire for the drug in adulthood, assuming they do not come into contact with the drug through "passive" drug administration (administration done by researcher); there may be a similarly increased risk for other drugs, however, it appears to only be associated with drugs having similar mechanisms of action, i.e. MA and amphetamine.

\section{Hypothesis III - There is a critical period for MA exposure during pre-/perinatal develop- ment in rats}

The term "critical developmental period" has existed in experimental psychology since 1921 and refers to a temporary interruption of the developmental process in certain stages of embryogenesis, which can have serious consequences (Stockard 1921). The author of the early theory further argued that the importance of the rate of development is not limited to embryogenesis, but also concerns postnatal ontogenesis (Stockard 1921). Scott (1962) followed this hypothesis, according to which postnatal development and growth depend on organized processes that can only be influenced while they are occurring, i.e. during critical development periods. Grobstein (1970) defines critical developmental periods as the existence of stages in which the development process is somehow sensitive to environmental factors.

In the sixties and seventies of the last century, Křeček (1978) attempted, in his studies of ontogenetic physiology, to find criteria for assessing whether certain developmental ages can be used to mark critical periods in development and whether permanent developmental changes can be induced by external intervention. According to his theory, these changes may not appear immediately after the intervention, i.e. some amount of time may pass between the application of the stimulus and the observable change. Additionally, critical periods can last for variable amounts of time and do not occur simultaneously for all functions; also, there can be several critical periods for a single function (Křeček 1978).

Critical developmental periods are characterized by triple transformations: a) increased sensitivity to external stimuli, b) transformation of functional systems, and c) changes in an individual's relationship to its environment (Křeček 1978). Based on these criteria, three main postnatal developmental periods can be defined: infantile (from birth to weaning, rats up to 20-25 days), juvenile (from weaning to sexual maturation), and adulthood (after maturation) (King 1958).

Synchronization of the development of functional systems and their mutual inductive action is an important part of the development of highly differentiated tissues and organ structures. Nerve cells acquire their identity during ontogenesis, creating orderly and accurate synaptic connections whose morphology and function are influenced not only by genetic factors but also by the external environment. Ontogenetic development of the nervous system can be influenced by factors associated with cell formation, inter-cell interactions, or mechanisms for cell migration, axonal growth, and myelination of synaptic connections. In many areas of the developing brain, the initial overproduction of neurons (up to $50 \%$ ) predominates, followed by a period of cell death during labor or the transition from early postnatal days to adulthood. These processes are responsible for the subsequent (sensitive) period of brain development (Clancy et al. 2007).

Brain development is divided into two processes, the growth process, and the maturation process. Human brain growth starts in the second trimester and neuronal replication ends before delivery, but the organization processes continue long after birth; most brain cells are formed before delivery.

In rats, neurogenesis occurs mostly in the cortical and subcortical regions between prenatal day (ED) 9.5 and postnatal day (PD) 15, in humans, cortical neurogenesis continues up to 2.5 years of age (Semple et al. 2013). The striatum (NAc, CP) and basal ganglia, structures important for motor activity, begin to form during ED 12-13 in rats, and at 5 weeks of gestation in humans. Neurogenesis of limbic system (hippocampus, amygdala) structures, important for learning, memory, emotion, and behavior processes occur in rats between ED 14-17, and in humans, it culminates around the $8^{\text {th }}$ week of gestation (Iaria et al. 2003, Rice and Barone 2000). Starting at that time, the first neurotransmitter cells gradually begin to appear (Rice and Barone 2000). The main neurotransmitter systems associated with the effects of psychostimulant drugs are the catecholamines (noradrenaline, dopamine) and indoles (serotonin).

Brain development continues with nerve cell maturation. Cells aggregate, create synaptic connections relatively quickly, but initially lack the functions typical 
of mature synapses. The peak in neurogenesis is estimated to occur at 40 weeks of gestation in humans, and at PD 7-14 in rats (first and second week postnatally) (Clancy et al. 2007). A study by Bockhorst et al. (2008) suggests that the most significant structural changes in the gray matter of rats occur during the first 5 days of postnatal development.

Drug abuse by women during pregnancy (Marwick 2000) is a very serious problem today. Many pregnant drug addicts switch from other hard drugs to MA because of its anorectic (helping mothers maintain their body weight) and stimulant (giving them energy) effects (Marwick 2000, Williams et al. 2003). Della Grotta et al. (2010) reported that $84.3 \%$ of pregnant, drug-addicted women use MA during the first trimester, $56.0 \%$ in the second trimester, and $42.4 \%$ of these women continue to use MA during the third trimester. From experimental animal studies examining the impact of psychostimulants on the development of offspring of drug-exposed mothers, it is clear that the timing of MA exposure during gestation or lactation significantly affects the degree of drug effect on the offspring of these mothers. Amphetamines, including MA, affect neuronal endings during CNS development and interfere with the maturation of brain structures, which begin to develop during the second half of the rat gestation period and continue until weaning (Andersen 2005). Therefore, applications during the early stages of pregnancy may not affect fetal brain development and cause functional changes in structures, however, application during the later stages of prenatal or postnatal development, i.e. during development and maturation of neurotransmitter systems, may be harmful since these stages are more sensitive to drug effects (Rice and Barone 2000, Williams et al. 2003).

\section{Drug abuse during gravidity}

Ultrasonography has shown that MA negatively affects intrauterine fetal development (Tronick and Beeghly 1999). In addition to the risk of miscarriages, premature births, and births with lower birth weight and growth retardation (Oro and Dixon 1987), these children can also experience heart defects, cleft lip, as well as morphological and functional changes in some CNS structures (Oro and Dixon 1987, Plessinger 1998). In utero prenatal MA exposure in rats involve either drug administration throughout the prenatal period or during shorter time intervals that are associated with a specific stage of fetal development (Jablonski et al. 2016). Rice and Barone (2000) compared the prenatal period of rat development (ED 1-21) to the first and second trimesters of gestation in humans: ED 1-9 in rats correlates with the first trimester and ED 10-21 corresponds to the second trimester. There are a number of experimental studies that describe the effects of prenatal MA exposure that is administered throughout the entire gestation period (ED 1-22 in rats).

\section{Drug abuse during lactation}

Most of the abused drugs can also enter breast milk, which means that the child is exposed to the drug postnatally during lactation (Fox 1965). However, there are differences in the perception of the lactation period in humans and rodents. The lactation period in humans starts at birth and continues until about 2.5 years of age, in rats it is from birth to weaning (PD 21) (Jablonski et al. 2016, Rice and Barone 2000). The fact that the brain matures over a longer period compared to other organs underlines the aforementioned differences between humans and rodents. Neuro-ontogenesis in humans is more critical during the later stages of gestation $\left(2^{\text {nd }}\right.$ and $3^{\text {rd }}$ trimester), whereas in rodents the nervous system matures mostly during the first two to three weeks after birth (Rice and Barone 2000). The timing of MA exposure during these critical stages of neuro-ontogenesis plays an important role in the mechanism of drug transmission: in this stage, the drug is transmitted to human offspring transplacentally, while in rats it is via breast milk during lactation. Rambousek et al. (2014) demonstrated the presence of MA not only in the plasma and brain of exposed mothers but also in breast milk taken from the stomach of the offspring of these mothers. Transmission of drugs via breast milk was also confirmed by the presence of MA and amphetamine in the serum (0.1-1 ng/ml) and brains (1-10 $\mathrm{ng} / \mathrm{g})$ of pups whose mothers' were exposed to MA at $5 \mathrm{mg} / \mathrm{ml} / \mathrm{kg}$ from the postpartum until weaning. There are few clinical studies that explain the transmission of MA through breast milk. In one study, Steiner et al. (1984) analyzed amphetamine concentrations in the plasma and maternal breast milk as well as drug concentrations in the urine of a child at days 10 and 42 post-partum. Analysis results revealed 3-7 times higher concentrations in breast milk compared to drug levels in maternal plasma. A small amount of MA was also found in the urine of the child. Based on this and other studies (Bartu et al. 2009), it is 
recommended that mothers do not breast-feed before the drug is excreted from the body (i.e. 24-48 h after use). Many experimental studies have also reported that one of the primary negative consequences of taking MA during lactation is reduced contact between the mother and pups (reviewed in Šlamberová 2012).

\section{Search for critical periods for MA exposure on neurodevelopment}

The negative effects of MA on the development of the offspring of drug-dependent mothers have been well investigated by numerous clinical and experimental studies (Šlamberová 2012). However, it is not yet fully known which period of gestation in humans is the most critical, i.e. the most sensitive to the negative effects of this drug. Therefore, the main objective of our studies have been to determine which of the various neuroontogenetic stages, when exposed to MA, have the most significant influence on adult rat behavior, thus identifying which critical developmental periods are most sensitive to the effects of this drug. To apply the conclusions of our preclinical study of rats to clinical trials, the application periods of MA exposure had to be matched to the equivalent developmental CNS periods in humans during the first, second, and third trimesters of pregnancy (Andersen 2003, Clancy et al. 2007, Rice and Barone 2000).

The results of our studies suggest that animals exposed to MA during ED 12-22 and PD 1-11, which correspond to the second and the third trimester, experienced significant behavioral deficits during development (Malinová-Ševčíková et al. 2014, Ševčíková et al. 2017) and in adulthood (Hrebíčková et al. 2014, Hrebíčková et al. 2017, Hrebíčková et al. 2016). This was found to be the case for all tests during comparisons to rats that received the drug during ED 1-11, which corresponds to the first trimester in humans.

Based on all of our findings, we concluded that the second half of prenatal development and the early postnatal period in rats are critical developmental periods for the effects of MA on adult animal behavior, and this period corresponds approximately to the second and third trimesters of prenatal development in humans. Our work has contributed to the elucidation of the mechanisms of drug addiction and the negative effects on developing offspring. The results deepened the current knowledge of the effects of MA on brain development during the prenatal and early postnatal periods. Our findings can be used to develop prevention programs and strategic approaches to drug treatment in pregnant women. Determining the critical period for MA effects can help to refine the timing of drug discontinuation in pregnant women, thus minimizing the drug's impact on CNS development in their children.

\section{Conclusion}

This review summarized the results from the laboratory of Prof. Šlamberová over the past 17 years dealing with the long-term effects of MA dependence on pregnant women, and the effect of the drug has on their offspring. Using animal models, we have worked to clarify the mechanisms of action of this drug. Current and future studies aim to determine the extent and role of genetic factors in the development of drug dependence.

\section{Conflict of Interest}

There is no conflict of interest.

\section{Acknowledgements}

This review is based on the extensive research conducted by our laboratory and the hard work of my graduate students Dr. Barbora Schutová, Dr. Lenka Hrubá, Dr. Eva Macúchová, Dr. Ivana Hrebíčková, and Mgr. Mária Ševčíková. The author expresses her appreciation to Thomas Secrest for editing the manuscript. This work was supported by research program PROGRES Q35 from Charles University, projects 18-03806S and 18-09296S from the Grant Agency of the Czech Republic, and ERDF/ESF project "PharmaBrain" (No. CZ.02.1.01/0.0/ 0.0/16_025/0007444).

\section{References}

ACUFF-SMITH KD, GEORGE M, LORENS SA, VORHEES CV: Preliminary evidence for methamphetamineinduced behavioral and ocular effects in rat offspring following exposure during early organogenesis. Psychopharmacology 109: 255-263, 1992.

ACUFF-SMITH KD, SCHILLING MA, FISHER JE, VORHEES CV: Stage-specific effects of prenatal d-methamphetamine exposure on behavioral and eye development in rats. Neurotoxicol Teratol 18: 199-215, 1996. 
ANDERSEN SL: Stimulants and the developing brain. Trends Pharmacol Sci 26: 237-243, 2005.

BARTU A, DUSCI LJ, ILETT KF: Transfer of methylamphetamine and amphetamine into breast milk following recreational use of methylamphetamine. Br J Clin Pharmacol 67: 455-459, 2009.

BELIN D, MAR AC, DALLEY JW, ROBBINS TW, EVERITT BJ: High impulsivity predicts the switch to compulsive cocaine-taking. Science 320: 1352-1355, 2008.

BERKE JD, HYMAN SE: Addiction, dopamine, and the molecular mechanisms of memory. Neuron 25: 515-532, 2000.

BERNÁŠKOVÁ K, MATĚJOVSKÁ I, ŠLAMBEROVÁ R: Postnatal challenge dose of methamphetamine amplifies anticonvulsant effects of prenatal methamphetamine exposure on epileptiform activity induced by electrical stimulation in adult male rats. Exp Neurol 229: 282-287, 2011.

BOCKHORST KH, NARAYANA PA, LIU R, AHOBILA-VIJJULA P, RAMU J, KAMEL M, WOSIK J, BOCKHORST T, HAHN K, HASAN KM, PEREZ-POLO JR: Early postnatal development of rat brain: in vivo diffusion tensor imaging. J Neurosci Res 86: 1520-1528, 2008.

BUBENÍKOVÁ-VALEŠOVÁ V, KAČER P, SYSLOVÁ K, RAMBOUSEK L, JANOVSKÝ M, SCHUTOVÁ B, HRUBÁ L, ŠLAMBEROVÁ R: Prenatal methamphetamine exposure affects the mesolimbic dopaminergic system and behavior in adult offspring. Int J Dev Neurosci 27: 525-530, 2009.

CHO DH, LYU HM, LEE HB, KIM PY, CHIN K: Behavioral teratogenicity of methamphetamine. J Toxicol Sci 16 (Suppl 1): 37-49, 1991.

CLANCY B, FINLAY BL, DARLINGTON RB, ANAND KJ: Extrapolating brain development from experimental species to humans. Neurotoxicology 28: 931-937, 2007.

DATTEL BJ: Substance abuse in pregnancy. Semin Perinatol 14: 179-187, 1990.

DEFALQUE RJ, WRIGHT AJ: Methamphetamine for Hitler's Germany: 1937 to 1945. Bull Anesth Hist 29: 21-24, 32, 2011.

DEJONG W: Relapse prevention: an emerging technology for promoting long-term drug abstinence. Int $J$ Addict 29: 681-705, 1994.

DELLA GROTTA S, LAGASSE LL, ARRIA AM, DERAUF C, GRANT P, SMITH LM, SHAH R, HUESTIS M, LIU J, LESTER BM: Patterns of methamphetamine use during pregnancy: results from the Infant Development, Environment, and Lifestyle (IDEAL) Study. Matern Child Health J 14: 519-527, 2010.

DIAGNOSTIC AND STATISTICAL MANUAL OF MENTAL DISORDERS FOURTH EDITION, American Psychiatric Association, 2000, $943 \mathrm{p}$.

ESTELLES J, RODRIGUEZ-ARIAS M, MALDONADO C, AGUILAR MA, MINARRO J: Gestational exposure to cocaine alters cocaine reward. Behav Pharmacol 17: 509-515, 2006.

EVERITT BJ, BELIN D, ECONOMIDOU D, PELLOUX Y, DALLEY JW, ROBBINS TW: Review. Neural mechanisms underlying the vulnerability to develop compulsive drug-seeking habits and addiction. Philos Trans R Soc Lond B Biol Sci 363: 3125-3135, 2008.

EVERITT BJ, ROBBINS TW: Neural systems of reinforcement for drug addiction: from actions to habits to compulsion. Nat Neurosci 8: 1481-1489, 2005.

FOX WM: Reflex-ontogeny and behavioural development of the mouse. Anim Behav 13: 234-241, 1965.

FRAŇKOVÁ S: Drug-induced changes in the maternal behavior of rats. Psychopharmacology (Berl) 53: 83-87, 1977.

FUJÁKOVÁ-LIPSKI M, KAPING D, ŠÍROVÁ J, HORÁČEK J, PÁLENÍČEK T, ZACH P, KLASCHKA J, KAČER P, SYSLOVÁ K, VRAJOVÁ M, BUBENÍKOVÁ-VALEŠOVÁ V, BESTE C, ŠLAMBEROVÁ R: Transgenerational neurochemical modulation of methamphetamine in the adult brain of the Wistar rat. Arch Toxicol 91: 3373-3384, 2017.

GERDEMAN GL, PARTRIDGE JG, LUPICA CR, LOVINGER DM: It could be habit forming: drugs of abuse and striatal synaptic plasticity. Trends Neurosci 26: 184-192, 2003.

GROBLER SR, CHIKTE U, WESTRAAT J: The $\mathrm{pH}$ levels of different methamphetamine drug samples on the street market in Cape Town. ISRN Dent 2011: 974768, 2011.

GROBSTEIN C: Environmental Influences on Genetic Expression. Government Printing Office, Washington, 1970.

HORGER BA, GILES MK, SCHENK S: Preexposure to amphetamine and nicotine predisposes rats to self-administer a low dose of cocaine. Psychopharmacology (Berl) 107: 271-276, 1992. 
HREBÍČKOVÁ I, MALINOVÁ-ŠEVČÍKOVÁ M, MACÚCHOVÁ E, NOHEJLOVÁ K, ŠLAMBEROVÁ R: Exposure to methamphetamine during first and second half of prenatal period and its consequences on cognition after long-term application in adulthood. Physiol Res 63 (Suppl 4): S535-S545, 2014.

HREBÍČKOVÁ I, ŠEVČÍKOVÁ M, MACÚCHOVÁ E, ŠLAMBEROVÁ R: How methamphetamine exposure during different neurodevelopmental stages affects social behavior of adult rats? Physiol Behav 179: 391-400, 2017.

HREBÍČKOVÁ I, ŠEVČÍKOVÁ M, NOHEJLOVÁ K, ŠLAMBEROVÁ R: Does effect from developmental methamphetamine exposure on spatial learning and memory depend on stage of neuroontogeny? Physiol Res 65 (Suppl 5): S577-S589, 2016.

HRUBÁ L, SCHUTOVÁ B, ŠLAMBEROVÁ R, POMETLOVÁ M, ROKYTA R: Effect of methamphetamine exposure and cross-fostering on sensorimotor development of male and female rat pups. Dev Psychobiol 51: $73-83,2009$.

IARIA G, PETRIDES M, DAGHER A, PIKE B, BOHBOT VD: Cognitive strategies dependent on the hippocampus and caudate nucleus in human navigation: variability and change with practice. $J$ Neurosci 23: 5945-5952, 2003.

JABLONSKI SA, WILLIAMS MT, VORHEES CV: Neurobehavioral effects from developmental methamphetamine exposure. Curr Top Behav Neurosci 29: 183-230, 2016.

KING JA: Parameters relevant to determining the effect of early experience upon the adult behavior of animals. Psychol Bull 55: 46-58, 1958.

K ǨEČEK J: Effect of ovarectomy of females and oestrogen administration to males during the neonatal critical period on salt intake in adulthood in rats. Physiol Bohemoslov 27: 1-5, 1978.

LERI F, FLORES J, RAJABI H, STEWART J: Effects of cocaine in rats exposed to heroin. Neuropsychopharmacology 28: 2102-2116, 2003.

LEVINE S: The ontogeny of the hypothalamic-pituitary-adrenal axis. The influence of maternal factors. Ann N Y Acad Sci 746: 275-288; discussion 289-293, 1994.

MACÚCHOVÁ E, ŠEVČÍKOVÁ M, HREBÍČKOVÁ I, NOHEJLOVÁ K, ŠLAMBEROVÁ R: How various drugs affect anxiety-related behavior in male and female rats prenatally exposed to methamphetamine. Int $J$ Dev Neurosci 51: 1-11, 2016.

MALANGA CJ, KOSOFSKY BE: Does drug abuse beget drug abuse? Behavioral analysis of addiction liability in animal models of prenatal drug exposure. Brain Res Dev Brain Res 147: 47-57, 2003.

MALINOVÁ-ŠEVČÍKOVÁ M, HREBÍČKOVÁ I, MACÚCHOVÁ E, NOVÁ E, POMETLOVÁ M, ŠLAMBEROVÁ R: Differences in maternal behavior and development of their pups depend on the time of methamphetamine exposure during gestation period. Physiol Res 63 (Suppl 4): S559-S572, 2014.

MARTIN JC, MARTIN DC, RADOW B, SIGMAN G: Growth, development and activity in rat offspring following maternal drug exposure. Exp Aging Res 2: 235-251, 1976.

MARWICK C: NIDA seeking data on effect of fetal exposure to methamphetamine. JAMA 283: 2225-2226, 2000.

ORO AS, DIXON SD: Perinatal cocaine and methamphetamine exposure: maternal and neonatal correlates. $J$ Pediatr 111: 571-578, 1987.

PARENT A: Extrinsic connections of the basal ganglia. TINS 13: 254-258, 1990.

PICCIRILLO M, ALPERT JE, COHEN DJ, SHAYWITZ BA: Amphetamine and maternal behavior: dose response relationships. Psychopharmacology (Berl) 70: 195-199, 1980.

PLESSINGER MA: Prenatal exposure to amphetamines. Risks and adverse outcomes in pregnancy. Obstet Gynecol Clin North Am 25: 119-138, 1998.

RAMBOUSEK L, KAČER P, SYSLOVÁ K, BUMBA J, BUBENÍKOVÁ-VALEŠOVÁ V, ŠLAMBEROVÁ R: Sex differences in methamphetamine pharmacokinetics in adult rats and its transfer to pups through the placental membrane and breast milk. Drug Alcohol Depend 139: 138-144, 2014.

REYNOLDS AK, RANDALL LO: Morphine and allied drugs. University of Toronto Press, Toronto, 1957.

RICE D, BARONE S JR: Critical periods of vulnerability for the developing nervous system: evidence from humans and animal models. Environ Health Perspect 108 (Suppl 3): 511-533, 2000. 
ROBINSON TE, BECKER JB: Enduring changes in brain and behavior produced by chronic amphetamine administration: a review and evaluation of animal models of amphetamine psychosis. Brain Res 396: 157-198, 1986.

ROCHA BA, MEAD AN, KOSOFSKY BE: Increased vulnerability to self-administer cocaine in mice prenatally exposed to cocaine. Psychopharmacology (Berl) 163: 221-229, 2002.

SCOTT JP: Critical periods in behavioral development. Science 138: 949-958, 1962.

SEMPLE BD, BLOMGREN K, GIMLIN K, FERRIERO DM, NOBLE-HAEUSSLEIN LJ: Brain development in rodents and humans: Identifying benchmarks of maturation and vulnerability to injury across species. Prog Neurobiol 106-107: 1-16, 2013.

SHUSTER L, YU G, BATES A: Sensitization to cocaine stimulation in mice. Psychopharmacology (Berl) 52: 185-190, 1977.

STEINER E, VILLEN T, HALLBERG M, RANE A: Amphetamine secretion in breast milk. Eur J Clin Pharmacol 27: 123-124, 1984.

STOCKARD CR: Developmental rate and structural expression: an experimental study of twins. 'double monsters' and single deformities, and the interaction among embryonic organs during their origin and development. Am J Anat 28: 115-266, 1921.

SUZUKI T, FUKUOKA Y, MORI T, MIYATAKE M, NARITA M: Behavioral sensitization to the discriminative stimulus effects of methamphetamine in rats. Eur J. Pharmacol 498: 157-161, 2004.

ŠEVČÍKOVÁ M, HREBÍČKOVÁ I, MACÚCHOVÁ E, ŠLAMBEROVÁ R: The influence of methamphetamine on maternal behavior and development of the pups during the neonatal period. Int J Dev Neurosci 59: 37-46, 2017.

ŠLAMBEROVÁ R: Drugs in pregnancy: the effects on mother and her progeny. Physiol Res 61 (Suppl 1): S123-S135, 2012.

ŠLAMBEROVÁ R, CHAROUSOVÁ P, POMETLOVÁ M: Maternal behavior is impaired by methamphetamine administered during pre-mating, gestation and lactation. Reprod Toxicol 20: 103-110, 2005.

ŠLAMBEROVÁ R, CHAROUSOVÁ P, POMETLOVÁ M: Methamphetamine administration during gestation impairs maternal behavior. Dev Psychobiol 46: 57-65, 2005.

ŠLAMBEROVÁ R, MACÚCHOVÁ E, NOHEJLOVÁ-DEYKUN K, SCHUTOVÁ B, HRUBÁ L, ROKYTA R: Gender differences in the effect of prenatal methamphetamine exposure and challenge dose of other drugs on behavior of adult rats. Physiol Res 62 (Suppl 1): S99-S108, 2013.

ŠLAMBEROVÁ R, POMETLOVÁ M, CHAROUSOVÁ P: Postnatal development of rat pups is altered by prenatal methamphetamine exposure. Prog Neuropsychopharmacol Biol Psychiatry 30: 82-88, 2006.

ŠLAMBEROVÁ R, POMETLOVÁ M, MACÚCHOVÁ E, NOHEJlOVÁ K, STUCHLÍK A, VALEŠ K: Do the effects of prenatal exposure and acute treatment of methamphetamine on anxiety vary depending on the animal model used? Behav Brain Res 292: 361-369, 2015.

ŠLAMBEROVÁ R, POMETLOVÁ M, ROKYTA R: Effect of methamphetamine exposure during prenatal and preweaning periods lasts for generations in rats. Dev Psychobiol 49: 312-322, 2007.

ŠLAMBEROVÁ R, POMETLOVÁ M, SCHUTOVÁ B, HRUBÁ L, MACÚCHOVÁ E, NOVÁ E, ROKYTA R: Do prenatally methamphetamine-exposed adult male rats display general predisposition to drug abuse in the Conditioned place preference test? Physiol Res 61 (Suppl 2): S129-S138, 2012.

ŠLAMBEROVÁ R, POMETLOVÁ M, SYLLABOVÁ L, MANČUŠKOVÁ M: Learning in the place navigation task, not the new-learning task, is altered by prenatal methamphetamine exposure. Brain Res Dev Brain Res 157: 217-219, 2005.

ŠLAMBEROVÁ R, SCHUTOVÁ B, HRUBÁ L, POMETLOVÁ M: Does prenatal methamphetamine exposure affect the drug-seeking behavior of adult male rats? Behav Brain Res 224: 50-86, 2011.

TRONICK EZ, BEEGHLY M: Prenatal cocaine exposure, child development, and the compromising effects of cumulative risk. Clin Perinatol 26: 151-171, 1999.

VALVASSORI SS, FREY BN, MARTINS MR, REUS GZ, SCHIMIDTZ F, INACIO CG, KAPCZINSKI F, QUEVEDO J: Sensitization and cross-sensitization after chronic treatment with methylphenidate in adolescent Wistar rats. Behav Pharmacol 18: 205-212, 2007. 
VAVŘÍNKOVÁ B, BINDER T, ŽIVNÝ J: Characteristics of a population of drug dependent pregnant women in the Czech Republic. (Article in Czech) Ceska Gynekol 66: 285-291, 2001.

VELA G, MARTIN S, GARCIA-GIL L, CRESPO JA, RUIZ-GAYO M, JAVIER FERNANDEZ-RUIZ J, GARCIALECUMBERRI C, PELAPRAT D, FUENTES JA, RAMOS JA, AMBROSIO E: Maternal exposure to delta9tetrahydrocannabinol facilitates morphine self-administration behavior and changes regional binding to central mu opioid receptors in adult offspring female rats. Brain Res 807: 101-109, 1998.

VITERI OA, SOTO EE, BAHADO-SINGH RO, CHRISTENSEN CW, CHAUHAN SP, SIBAI BM: Fetal anomalies and long-term effects associated with substance abuse in pregnancy: a literature review. Am J Perinatol 32: 405-416, 2015.

VOLKOW ND, WISE RA: How can drug addiction help us understand obesity? Nat Neurosci 8: 555-560, 2005.

VORHEES CV, ACUFF-SMITH KD: Prenatal methamphetamine-induced anophthalmia in rats. Neurotoxicol Teratol 12: 409, 1990.

WILLIAMS MT, MORAN MS, VORHEES CV: Refining the critical period for methamphetamine-induced spatial deficits in the Morris water maze. Psychopharmacology (Berl) 168: 329-338, 2003.

YAMAMOTO Y, YAMAMOTO K, FUKUI Y, KURISHITA A: Teratogenic effects of methamphetamine in mice. Nippon Hoigaku Zasshi 46: 126-131, 1992.

YAMAMOTOVÁ A, ŠLAMBEROVÁ R: Behavioral and antinociceptive effects of different psychostimulant drugs in prenatally methamphetamine-exposed rats. Physiol Res 61 (Suppl 2): S139-S147, 2012. 